\title{
REVIEW
}

\section{Discharge of nutrient wastes from salmon farms: environmental effects, and potential for integrated multi-trophic aquaculture}

\author{
Xinxin Wang ${ }^{1, *}$, Lasse Mork Olsen ${ }^{1}$, Kjell Inge Reitan ${ }^{2}$, Yngvar Olsen ${ }^{1}$ \\ ${ }^{1}$ Trondheim Biological Station, Department of Biology, Norwegian University of Science and Technology, 7491 Trondheim, \\ Norway \\ ${ }^{2}$ SINTEF Fisheries and Aquaculture, 7465 Trondheim, Norway
}

\begin{abstract}
We quantified release rates of carbon $(\mathrm{C})$, nitrogen $(\mathrm{N})$ and phosphorus $(\mathrm{P})$ waste from Norwegian salmon farms in 2009 in order to evaluate the theoretical environmental influence on surrounding waters and the potential for integrated multi-trophic aquaculture (IMTA) driven by salmon aquaculture. Of the total feed input, $70 \% \mathrm{C}, 62 \% \mathrm{~N}$ and $70 \% \mathrm{P}$ were released into the environment, equivalent to an annual discharge of about 404000 , 50600 and $9400 \mathrm{t}$ of $\mathrm{C}, \mathrm{N}$ and $\mathrm{P}$, respectively, based on total salmon production of $1.02 \times 10^{6} \mathrm{t}$. We predicted that $48 \%$ of feed $\mathrm{C}$ was respired as $\mathrm{CO}_{2}, 45 \%$ of feed $\mathrm{N}$ was excreted as dissolved inorganic N (DIN), and 18\% of feed P was excreted as dissolved inorganic P (DIP). Approximately $44 \%$ of feed $\mathrm{P}$ was released as particles, dominating solid wastes. The mean food conversion ratio (feed supplied per fish produced) of Norwegian salmon farms was $1.16 \pm 0.08 \mathrm{SE}$ in 2009. Estimates of the potential for IMTA driven by salmon farming showed a far higher potential for seaweed production based on the released DIN than for mussel production based on released appropriately sized particulate organic carbon (POC). The daily volumetric loading rates of DIN from salmon farms (range for counties: 40 to $501 \mu \mathrm{g} \mathrm{N} \mathrm{m}{ }^{-3}$ $\mathrm{d}^{-1}$ ) were $<15 \%$ of the natural loading rate of nitrate from deep water, suggesting that the nutrient loading rate is within safe limits.
\end{abstract}

KEY WORDS: Cage aquaculture · Atlantic salmon · Nutrient wastes · Feed conversion ratio • FCR $\cdot$ Integrated multi-trophic aquaculture $\cdot$ IMTA $\cdot$ Seaweed $\cdot$ Blue mussels

Resale or republication not permitted without written consent of the publisher

\section{INTRODUCTION}

Global aquaculture is developing rapidly and is the fastest growing food producing sector (Troell et al. 2009, Abreu et al. 2011), with nearly half of the world's seafood supply now sourced from aquaculture (FAO 2010). Cage aquaculture has been practiced for years in many countries worldwide, and technology has developed steadily over the last few decades (Enell 1995, Islam 2005). For example, global aquaculture production of marine Atlantic salmon Salmo salar and rainbow trout Oncorhynchus mykiss increased from $0.92 \times 10^{6} \mathrm{t}$ in 1999 to $1.74 \times 10^{6} \mathrm{t}$ in 2009 (FAO, online query: www.fao. org/fishery/statistics/global-aquaculture-production/ query/en).

In Norway, intensive open cage culture with a continuous water exchange with surrounding waters 
(Troell \& Norberg 1998) has expanded significantly over the last few decades (Skogen et al. 2009). Cage aquaculture can release a considerable amount of biogenic waste such as organic wastes and inorganic nutrients that are generated in the production process (Troell \& Norberg 1998, Cheshuk et al. 2003, Vassallo et al. 2006, Redmond et al. 2010). The rapid expansion of cage aquaculture has raised a general concern about increasing amounts of solid and dissolved nutrients released to the aquatic environment (Perez 2002, Whitmarsh et al. 2006, Redmond et al. 2010, Azevedo et al. 2011, Skriptsova \& Miroshnikova 2011).

Fish farming releases carbon (C), nitrogen (N) and phosphorus (P) waste (Fig. 1). Dissolved inorganic N (i.e. $\mathrm{NH}_{3}{ }^{+}$) and $\mathrm{P}$ (i.e. $\mathrm{PO}_{4}{ }^{3-}$ ) (DIN and DIP, respectively) are released through excretion, and inorganic $\mathrm{C}$ as $\mathrm{CO}_{2}$ is released through respiration. Particulate organic $\mathrm{C}, \mathrm{N}$ and $\mathrm{P}$ (POC, PON and POP, respectively) are released through defecation and loss of feed. Dissolved organic C, N and P (DOC, DON and DOP, respectively) are generated through dissolution of particulate organic fractions (Olsen \& Olsen 2008).

These different nutrient components have the potential to influence different parts of the marine ecosystem. Inorganic nutrients such as DIN and DIP are readily available for phytoplankton and macroalgae (Troell et al. 2003, 2009) and uptake can be fast, although it may take several days before the phytoplankton biomass responds to this increase (Olsen \& Olsen 2008). Large faecal particles and uneaten feed sink rapidly and may accumulate in sediments on the seafloor (Cromey et al. 2002, Olsen \& Olsen 2008, Nickell et al. 2009) where they may be consumed by detritus-eating animals. Small particles of waste can remain in suspension and then be consumed by filter-feeding zooplankton or by visual feeders, such as fish, in the water column, or by mussels (Olsen \& Olsen 2008, Troell et al. 2009). DON and DOP are dissolved from feed and faecal particles, and may constitute small $\mathrm{N}$ - and P-containing molecular species such as, for example, amino acids and nucleotides, but mostly comprise complex dissolved chemical compounds $(<0.2 \mu \mathrm{m})$ that are avail-

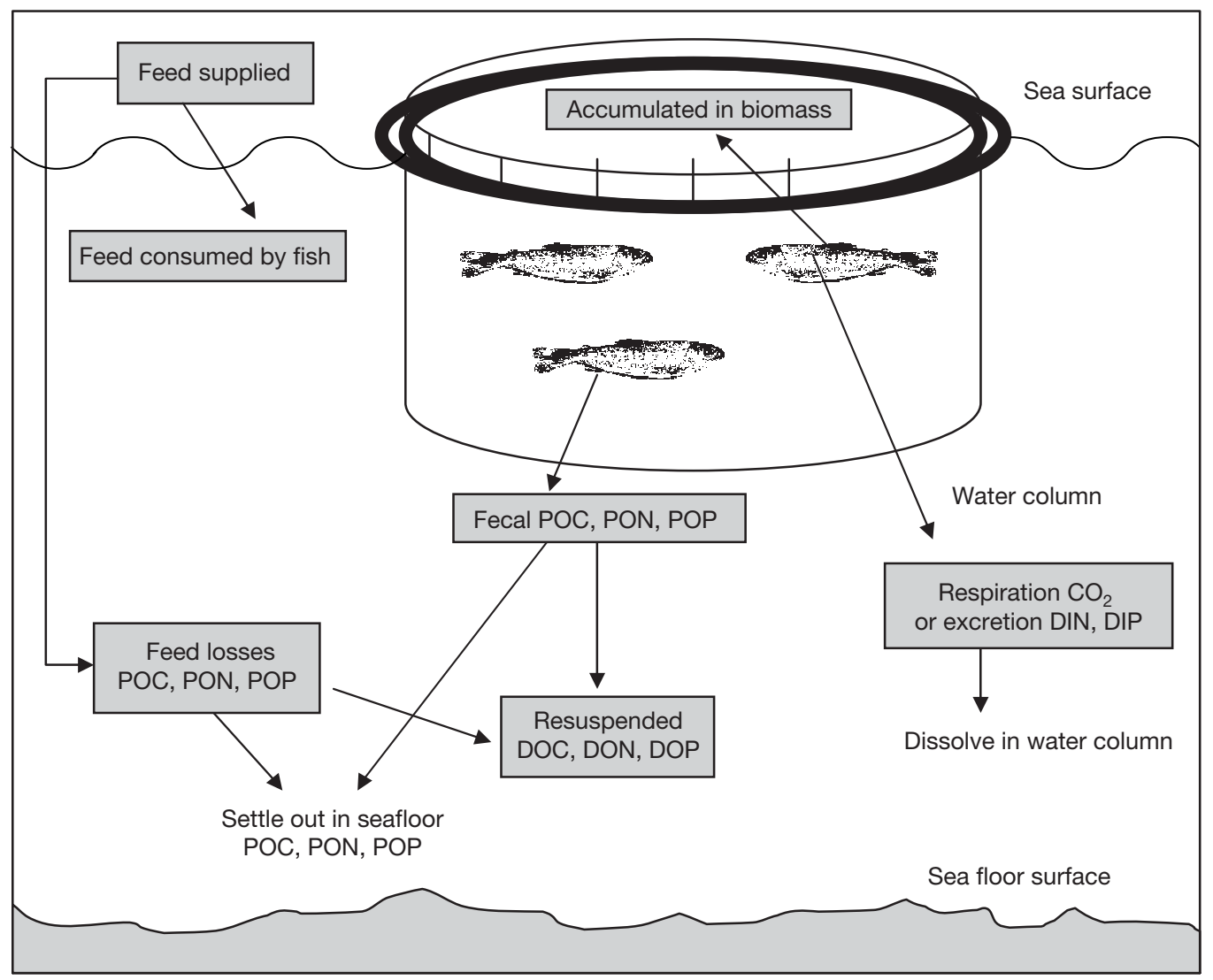

Fig. 1. The flow and fate of nutrient components from a salmon cage system. Dissolved inorganic nitrogen and phosphorus (DIN and DIP, respectively) are released through excretion, and inorganic carbon $\left(\mathrm{CO}_{2}\right)$ through respiration. Particulate organic $\mathrm{C}, \mathrm{N}$ and $\mathrm{P}$ (POC, PON and POP, respectively) are released through defecation and feed loss. Dissolved organic $\mathrm{C}, \mathrm{N}$ and $\mathrm{P}$ (DOC, DON and DOP, respectively) are resuspended from faeces and feed particles 
able for bacteria and for phytoplankton over a longer time scale (Palenik \& Morel 1990, Fan et al. 2003, Stoecker \& Gustafson 2003).

One of the main challenges facing aquaculture today is sustaining a continued increase in fish production while minimizing the impact on the environment (Sugiura et al. 2006, Navarrete-Mier et al. 2010). The salmon aquaculture industry has taken a number of steps to reduce nutrient release from salmon farming facilities. These efforts include optimizing feed composition and improvements in feed digestibility and feeding technology (Cheshuk et al. 2003, Islam 2005). These measures reduced nutrient loading and mitigated pressure on the environment. These improvements of environmental technologies of cage culture have been significant in European aquaculture over recent decades; for instance, the mean economic feed conversion ratio (FCR) for the Norwegian salmon industry was 2.08 in 1974 but can now reach as low as 1.0 to 1.1 (Enell 1995, Piedrahita 2003, Islam 2005).

Integrated multi-trophic aquaculture (IMTA) is a practical and viable solution for mitigating the possible negative environmental impacts of waste produced by fish aquaculture. It works by exploiting fish waste as a food resource for extractive and filter feeding species at lower trophic levels, thereby also giving an added value to the investment in feed for cage aquaculture (Barrington et al. 2001). IMTA has been practiced for centuries in Asia (Li 1987, Fang et al. 1996, Qian et al. 1996), where it is now commercially successful at industrial scales. An example is the cultivation of scallop, kelp and abalone in the marine IMTA system of Sungo Bay, China, (Fang et al. 1996, Troell et al. 2009). The approach is now also becoming widely accepted in western countries (Troell et al. 2009, Abreu et al. 2011, MacDonald et al. 2011) and several pilot experiments using IMTA have recently been conducted in Canada, Scotland and Australia (Stirling \& Okumus 1995, Cheshuk et al. 2003, Barrington et al. 2010). In the Bay of Fundy, Canada, blue mussels Mytilus edulis and kelps (Saccharina latissima and Alaroa esculenta) reared close to Atlantic salmon cages exhibited growth rates that were 46 and $50 \%$ higher, respectively, than at control sites. The products are now being sold commercially, adding value to salmon production (Reid et al. 2009, Troell et al. 2009).

Norway has more recently made efforts to develop IMTA, driven by waste generated by the large salmon producing sector (e.g. Handå 2012). It is important to quantify the different nutrient components released by fish farms in order to fully understand the potential of IMTA and the possible effects on the coastal ecosystems, and to optimize the design and nutrient recovery efficiency of IMTA systems (Reid et al. 2009, Dalsgaard \& Pedersen 2011). The objectives of the present study were to quantify the release rate of inorganic and organic nutrient wastes generated in Norwegian salmon aquaculture, and to make a preliminary evaluation of nutrient loading rates of coastal waters and the theoretical potential of salmon-driven IMTA.

\section{MATERIALS AND METHODS}

\section{Estimating release rate of wastes}

The release rate of waste from cage aquaculture can be estimated using a simple mass balance principle, provided that the required input information is available (Sterner \& George 2000, Olsen \& Olsen 2008, Reid et al. 2009). The main data input used to estimate the release rates of particulate and dissolved $\mathrm{C}, \mathrm{N}$ and $\mathrm{P}$ wastes were monthly statistics on feed used and fish production made available by the Norwegian Fish Farmer Association (FHL). Further required inputs were: data on the digestibility (assimilation efficiency) of $\mathrm{C}, \mathrm{N}$ and $\mathrm{P}$ components of the feed and feed loss, obtained from feed producers and the published results of other studies; data on $\mathrm{C}, \mathrm{N}$ and $\mathrm{P}$ stoichiometry of fish and feed that were derived from other studies and our own measurements; and data on water content of feed and fish taken from published literature. The values of the coefficients used in the mass balance calculations are listed in Table 1.

Mass balance of $\mathrm{C}, \mathrm{N}$ and $\mathrm{P}$ in fish

The mass balance for fish (f) consuming food can be represented by:

$$
I_{\mathrm{f}}=A_{\mathrm{f}}+F_{\mathrm{f}}=G_{\mathrm{f}}+E_{\mathrm{f}}+F_{\mathrm{f}}
$$

where $I$ is food intake, $A$ is assimilated food, $F$ is defecation, $G$ is growth or retention in biomass and $E$ is excretion. The assimilated food is the part that is digested by fish and taken up in tissues, and assimilation per ingestion is termed assimilation efficiency (AE) and is compatible to the digestion efficiency reported by feed manufacturers. The AE for $\mathrm{C}, \mathrm{N}$, or $\mathrm{P}$ was calculated as:

$$
\mathrm{AE}_{\mathrm{f}}=A_{\mathrm{f}} / I_{\mathrm{f}}
$$


Table 1. Values of model coefficients for water content of feed and fish, the assimilation efficiency (AE) of feed carbon (C), nitrogen $(\mathrm{N})$ and phosphorus $(\mathrm{P})$, the content of $\mathrm{C}, \mathrm{N}$ and $\mathrm{P}$ in feed and fish, and the leaching rate (i.e. soluble fraction) of faecal and feed C, N and P. DW: dry weight; WW: wet weight

\begin{tabular}{|c|c|c|}
\hline Coefficient & Value & References \\
\hline Feed loss $(\%)$ & 3 & $\begin{array}{l}\text { Corner et al. (2006), } \\
\text { Reid et al. (2009) }\end{array}$ \\
\hline Water in feed (\%DW) & 4 & Piedecausa et al. (2010) \\
\hline Dry matter in fish (\%WW) & 33.5 & Talbot et al. (1986) \\
\hline \multicolumn{3}{|l|}{ Carbon $(\mathrm{C})$} \\
\hline $\mathrm{AE}$ & 0.8 & $\begin{array}{l}\text { Cheshuk et al. (2003), } \\
\text { Corner et al. (2006) }\end{array}$ \\
\hline $\mathrm{C}$ content in feed $(\% \mathrm{DW})$ & 51 & $\begin{array}{l}\text { Petersen et al. (2005), } \\
\text { Corner et al. (2006) }\end{array}$ \\
\hline $\mathrm{C}$ content in fish (\%DW) & 50 & Olsen \& Olsen (2008) \\
\hline Soluble fraction (\%DW) & 15 & Chen et al. (2003) \\
\hline \multicolumn{3}{|l|}{ Nitrogen $(\mathrm{N})$} \\
\hline $\mathrm{AE}$ & 0.85 & $\begin{array}{l}\text { T. Lea, Skretting AS } \\
\text { pers. comm. }\end{array}$ \\
\hline $\mathrm{N}$ content in feed $(\% \mathrm{DW})$ & 7.2 & $\begin{array}{l}\text { Gillibrand et al. (2002), } \\
\text { Mente et al. (2006) }\end{array}$ \\
\hline $\mathrm{N}$ content in fish (\%WW) & 3 & $\begin{array}{l}\text { Ackefors \& Enell (1990), } \\
\text { Davies \& Slaski (2003) }\end{array}$ \\
\hline Soluble fraction (\%DW) & 15 & Chen et al. (2003) \\
\hline \multicolumn{3}{|l|}{ Phosphorus (P) } \\
\hline $\mathrm{AE}$ & 0.5 & $\begin{array}{l}\text { Reid et al. (2009), } \\
\text { Bureau et al. (2003) }\end{array}$ \\
\hline $\mathrm{P}$ content in feed (\%DW) & 1.2 & $\begin{array}{l}\text { Petersen et al. (2005), } \\
\text { Reid et al. (2009) }\end{array}$ \\
\hline P content in fish (\%WW) & 0.40 & Talbot et al. (1986) \\
\hline Soluble fraction (\%DW) & 15 & Sugiura et al. (2006) \\
\hline
\end{tabular}

for each individual element. The $\mathrm{C}, \mathrm{N}$ and $\mathrm{P}$ assimilated in the food can be used for growth and weight increments or may be released through respiration and excretion. The growth efficiency (GE) is an ecological term and expresses production yield, and is calculated as:

$$
\mathrm{GE}_{\mathrm{f}}=G_{\mathrm{f}} / I_{\mathrm{f}}
$$

for each element with production and consumption expressed in the same units (e.g. $\mathrm{g} \mathrm{d}^{-1}$ ). Excreted $\mathrm{C}$ is $\mathrm{CO}_{2}$ released in respiration, whereas $\mathrm{N}$ and $\mathrm{P}$ are mainly excreted in the form of ammonia $\left(\mathrm{NH}_{3}\right)$ released over the gills and $\mathrm{PO}_{4}{ }^{3-}$ in urine. The amount of nutrients excreted $\left(E_{\mathrm{f}}\right)$ is equal to the amount of assimilated nutrients minus the amount of nutrients retained in fish biomass, and can be represented by the following equation:

$$
E_{\mathrm{f}}=A_{\mathrm{f}}-G_{\mathrm{f}}=\left(I_{\mathrm{f}} \times \mathrm{AE}_{\mathrm{f}}\right)-G_{\mathrm{f}}
$$

for each individual element, where $I$ is the total dry feed intake multiplied by feed content per dry weight (DW) of the nutrient concerned ( $\mathrm{C}, \mathrm{N}$ or P). AE for $\mathrm{C}$,
$\mathrm{N}$ and $\mathrm{P}$ can be obtained from feed manufactures and literature (Table 1). $G$ is the $\mathrm{C}, \mathrm{N}$ and $\mathrm{P}$ harvested as fish biomass and can be calculated as fish production multiplied by $\mathrm{C}, \mathrm{N}$ and $\mathrm{P}$ contents in fish. Of the food ingested, a proportion will not be digested by fish, but released as faecal particles. The indigestible content in the feed will mainly determine the fraction of faeces produced per feed consumed. $F_{\mathrm{f}}$ can be estimated as:

$$
F_{\mathrm{f}}=I_{\mathrm{f}}-A_{\mathrm{f}}=I_{\mathrm{f}} \times\left(1-\mathrm{AE}_{\mathrm{f}}\right)
$$

Mass balance of $\mathrm{C}, \mathrm{N}$ and $\mathrm{P}$ on the fish farm level

The waste emission from fish farms differs from that from individual fish because a proportion of feed will be lost as particles and some fish individuals will die (Davies \& Slaski 2003, Olsen \& Olsen 2008). Dead salmon are usually collected for destruction and land deposition, so are not lost directly to the environment. In our calculations, mortality is a part of fish production, and we have therefore assumed that the additional mortality is insignificant in the context of the overall transfer of matter.

Feed losses previously represented a significant source of particulate waste from fish farms (20 to $40 \%$ of total feed input; Beveridge 1987, Islam 2005, Reid et al. 2009), but feeding is now better controlled and losses are lower than in the past (Cromey et al. 2002, Bureau et al. 2003, Davies \& Slaski 2003, Mente et al. 2006). In our calculations, we assumed that $3 \%$ of the total feed input was lost uneaten. According to this, the feed input to the farm $\left(I_{F},{ }^{\prime} F^{\prime}\right.$ for farm level) equals total fish assimilation $\left(A_{\mathrm{F}}\right)$ and defecation $\left(F_{\mathrm{F}}\right)$ plus the feed loss $\left(L_{\mathrm{F}}\right)$ :

$$
I_{\mathrm{F}}=A_{\mathrm{F}}+F_{\mathrm{F}}+L_{\mathrm{F}}
$$

The loss of particulate organic material of element $\mathrm{X}\left(L_{\mathrm{POX}}\right)$, where $\mathrm{X}$ is $\mathrm{C}, \mathrm{N}$ or $\mathrm{P}$, from the fish farm equals the total defecation $\left(F_{\mathrm{F}}\right)$ plus the feed loss $\left(L_{\mathrm{F}}\right)$ of the element:

$$
L_{\mathrm{POX}}=F_{\mathrm{X}}+L_{\mathrm{X}}
$$

A fraction of the particles will dissolve and become dissolved organic material (DOX). According to Chen et al. (2003), approximately $15 \%$ of the $\mathrm{C}$ and $\mathrm{N}$ in faeces were leached after a few minutes in water, and there was no further significant leaching thereafter. Moreover, approximately $15 \%$ of faecal P becomes soluble in minutes or hours (Sugiura et al. 2006). Feed loss is relatively low from modern salmon farming where feeding is normally camera assisted 
and losses are monitored using either camera or acoustic devices installed to detect uneaten pellets. We assumed the dissolution rate of lost feed particles to be the same as that for faeces in our mass balance model. The loss of dissolved organic material ( $\left.L_{\mathrm{DOX}}\right)$ can accordingly be calculated as:

$$
L_{\text {DOX }}=L_{\mathrm{POX}} \times \mathrm{SF}
$$

where SF is the soluble fraction per dry weight of faeces and feed particles. The net loss of particulate matter $\left(L_{\mathrm{NPOX}}\right)$ then equals particulate waste nutrients $\left(L_{\mathrm{POX}}\right)$ minus dissolved organic nutrients $\left(L_{\mathrm{DOX}}\right)$ leaching from particulate matters generated through defecation and feed loss, i.e.:

$$
L_{\mathrm{NPOX}}=L_{\mathrm{POX}}-L_{\mathrm{DOX}}
$$

\section{Values of coefficients}

The input values used in the calculations are reviewed in Table 1. Salmon feed pellets have been reported to have a water content of $4 \%$ of DW (Piedecausa et al. 2010). DW per wet weight (WW) of Atlantic salmon has been determined in the literature to be $34 \%$ (Talbot et al. 1986). The proportion of feed that is lost varies with type of feed, feeding regimes and regions. Early studies in open cage aquaculture revealed loss rates in the range of 1 to $40 \%$ for different feed types and feeding regimes (Gowen et al. 1985, Beveridge 1987, Hall 1990, Troell \& Norberg 1998, Islam 2005). In a more recent study of feeding assisted by modern technology, feed loss was found to be below $5 \%$ of the input (Cromey et al. 2002, Bureau et al. 2003, Reid et al. 2009). The Norwegian salmon farmers claim that feed loss in modern salmon production, using camera assisted feeding control and acoustic registration of lost feed pellets, is negligible and that there are no economic and environmental incentives to further reduce feed loss. Therefore, a feed loss rate of $3 \%$ appears to be a reasonable assumption for modern salmon production (Cromey et al. 2002, Corner et al. 2006, Reid et al. 2009). The average whole body $P$ composition in salmonids was reported to be $0.4 \%$ of WW (Talbot et al. 1986). The average values for digestibility (i.e. AE) of feed ingredients, the $\mathrm{C}, \mathrm{N}$ and $\mathrm{P}$ composition of feed and fish, and the soluble fraction of $\mathrm{C}, \mathrm{N}$ and $\mathrm{P}$ from resuspended particles were taken from the literature, fish farm managers and from feed producers (Table 1).

The accuracy of the input data can be important for model performance. Tests of sensitivity for specific input variables, such as digestibility of $\mathrm{N}$ and $\mathrm{P}$ components in the feed and feed loss rate, were undertaken to elucidate the dependency of model predictions of dissolved inorganic and particulate wastes on these input variables.

\section{Potential of macroalgae and blue mussel production}

Macroalgae have the ability to take up and remove dissolved inorganic nutrients from fish farms in openwater IMTA systems (Buschmann et al. 1996, Martínez-Aragón et al. 2002, Kraemer et al. 2004). DIN $\left(\mathrm{NH}_{4}{ }^{+}+\mathrm{NO}_{3}{ }^{-}+\mathrm{NO}_{2}{ }^{-}\right)$is the limiting factor determining the productivity of seaweed in many marine environments (Troell et al. 2009, á Norði et al. 2011). The removal rate of DIN released from fish tanks varies from 35 to $100 \%$ at different densities and under different experimental designs (Buschmann et al. 1996, Troell et al. 2003). However, the removal rates of macroalgae in an open-water IMTA system might be lower due to the high dilution. Troell et al. (1997) reported that 1 ha of Gracilaria chilensis co-cultured in a salmon farm with an annual production of $227 \mathrm{t}$, and a stocking density of $0.5 \mathrm{~kg} \mathrm{WW} \mathrm{m}^{-2}$ at 2 depths (1 and $3 \mathrm{~m}$ ), could remove approximately $6.5 \%$ of the dissolved nitrogen from the fish farm. Higher cultiva-

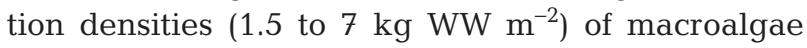
were used to remove dissolved inorganic nutrients in fish tank effluents in previous studies (Buschmann et al. 1994, Abreu et al. 2011). To evaluate the potential for seaweed production co-cultured with salmon in open-water IMTA systems, we assumed that 10 to $30 \%$ of total DIN released from salmon aquaculture can be assimilated by macroalgae. Production of seaweed co-cultured in open-water IMTA systems was assumed to be $70 \mathrm{t}$ fresh seaweed $\mathrm{ha}^{-1}$ (Yang et al. 2006)

Previous studies demonstrated that suspension feeders such as blue mussels are capable of consuming particles of appropriate size released from fish farms (Stirling \& Okumus 1995, Peharda et al. 2007, MacDonald et al. 2011). Wong \& Piedrahita (2000) demonstrated that $30 \%$ of the total particulate waste released from rainbow trout (20 to $40 \mathrm{~cm}$ length) is suspended solids. Blue mussels can filter particles of sizes between 2 and $1000 \mu \mathrm{m}$ with high retention efficacy when feeding on particles $\geq 4 \mu \mathrm{m}$ (Møhlenberg \& Riisgård 1978, Reid et al. 2009). Elberizon \& Kelly (1998) reported that around $70 \%$ of the total solid waste (uneaten feed and faeces) from salmon (mean salmon weight $25 \mathrm{~g}$ ) held in tanks passes through the 
$1000 \mu \mathrm{m}$ meshes. For blue mussels, we assumed that only 10 to $30 \%$ of the suspended solids $(30 \%$ of the total particulate) were of an appropriate size for mussels to capture and consume in an open-water IMTA system. We further assumed a mussel growth yield of $20 \%$ for the consumed suspended solids (Olsen et al. 2011). These assumptions together imply that 0.6 to $1.8 \%$ of the total particulate waste from salmon farming can be incorporated into mussel biomass.

The mean $\mathrm{N}$ content of macroalgae was assumed to be $4.2 \%$ of DW (Yang et al. 2006), and the C content of dry flesh of blue mussel was assumed to be $37 \%$ (Smaal \& Vonck 1997). The dry matter contents of fresh seaweed and blue mussel from our own experiments were approximately $15 \%$ and $25 \%$, respectively.

\section{Volumetric loading rate of inorganic nutrients}

The volume of coastal water into which the inorganic nutrients from salmon farms are drained cannot easily be estimated. Future management will require an ecosystem approach, but there are few natural physical borders along the Norwegian coast that can serve as boundaries to demarcate separate coastal ecosystems of a size suitable for the kind of ecosystem-based management approaches implemented elsewhere in Europe (Tett 2008). As a first approximation, we have assumed that the nutrients released from salmon farming within the 9 counties that cover the entire west-facing coast of Norway (Norwegian Sea/North Sea) where salmon production is undertaken, are drained into national coastal waters of each county. We calculated the area of these coastal waters as sea area inside Norwegian territorial waters (available from Statens Kartverk, www.norgeskart. no) minus the area between territorial waters and the baseline, which was estimated from maps using image analysis. The volume of the surface mixed layer (to 15 $m$ depth) of these receiving waters was estimated as area $\times$ depth. These are the euphotic waters where photosynthesis takes place and into which most nutrients drain. The volumetric loading rates of inorganic $\mathrm{N}$ and $\mathrm{P}$ in euphotic waters originating from salmon farming in the counties were finally estimated as mass of inorganic nutrients released per time and volume of receiving waters.

\section{Statistics}

Temperature, growth rate, FCR and GE were tested for statistical significance using a 1-way analysis of variance (ANOVA) with Tukey's multiple comparison tests, and differences were considered significant at the $\mathrm{p}<0.05$ level. Means are given with standard error. The statistical analyses were performed by SPSS (17.0) for Windows. Tables were made using Excel 2003, and figures using Sigmaplot 10.0 .

\section{RESULTS}

\section{Salmon production and feed conversion}

The total amount of feed pellets used in all Norwegian salmon farms was $1.17 \times 10^{6} \mathrm{t}$, and total salmon production was $1.02 \times 10^{6}$ t WW in 2009, according to FHL statistics. Generally, the sea temperature of mixed euphotic waters (0 to $15 \mathrm{~m}$ depth) for all counties began to increase in April, reached its highest value in August, and then gradually decreased from September (Fig. 2A). The average annual temperature over the year decreased from south to north (Fig. 2B).

Fig. 2C shows the amounts of seasonal feed used (DW) and fish produced (WW) by Norwegian salmon farms in 2009. Production peaked from July to November, and there was a significant interannual variation in fish production, mainly dependent on the standing biomass of fish and the temperature during the year. On average, $67 \%$ of feed consumption and $68 \%$ of production took place in the summer-autumn period (June-November).

Production in individual counties ranged from $195315 \mathrm{t}$ in Nordland (NOR), which produced almost $20 \%$ of the salmon $\left(1.02 \times 10^{6} \mathrm{t}\right.$ WW $)$ in Norway in 2009, to 51105 t in Finmark (FIN), which accounted for $5 \%$ ot total production. Other counties of importance for salmon production included Hordaland (HOR, 16\%), Møre and Romsdal (MRO, 12\%) and Sør-Trøndelag (STR, 12\%).

The absolute daily growth rate of salmon for the different counties followed the same trend as the annual production (Fig. 3A). The mean FCR of fish farms (dry feed used per wet biomass of fish produced) in southern counties was slightly higher than in northern counties (Fig. 3B), though the differences were not statistically significant (ANOVA, $p=0.053$ ). The mean economic FCR of Norwegian salmon farms in 2009 was $1.16 \pm 0.08$.

The GE values showed small differences between the counties, with slightly higher yields in the northern counties (from STR to FIN; Fig. 3C,D). The differences between southern and northern counties were 

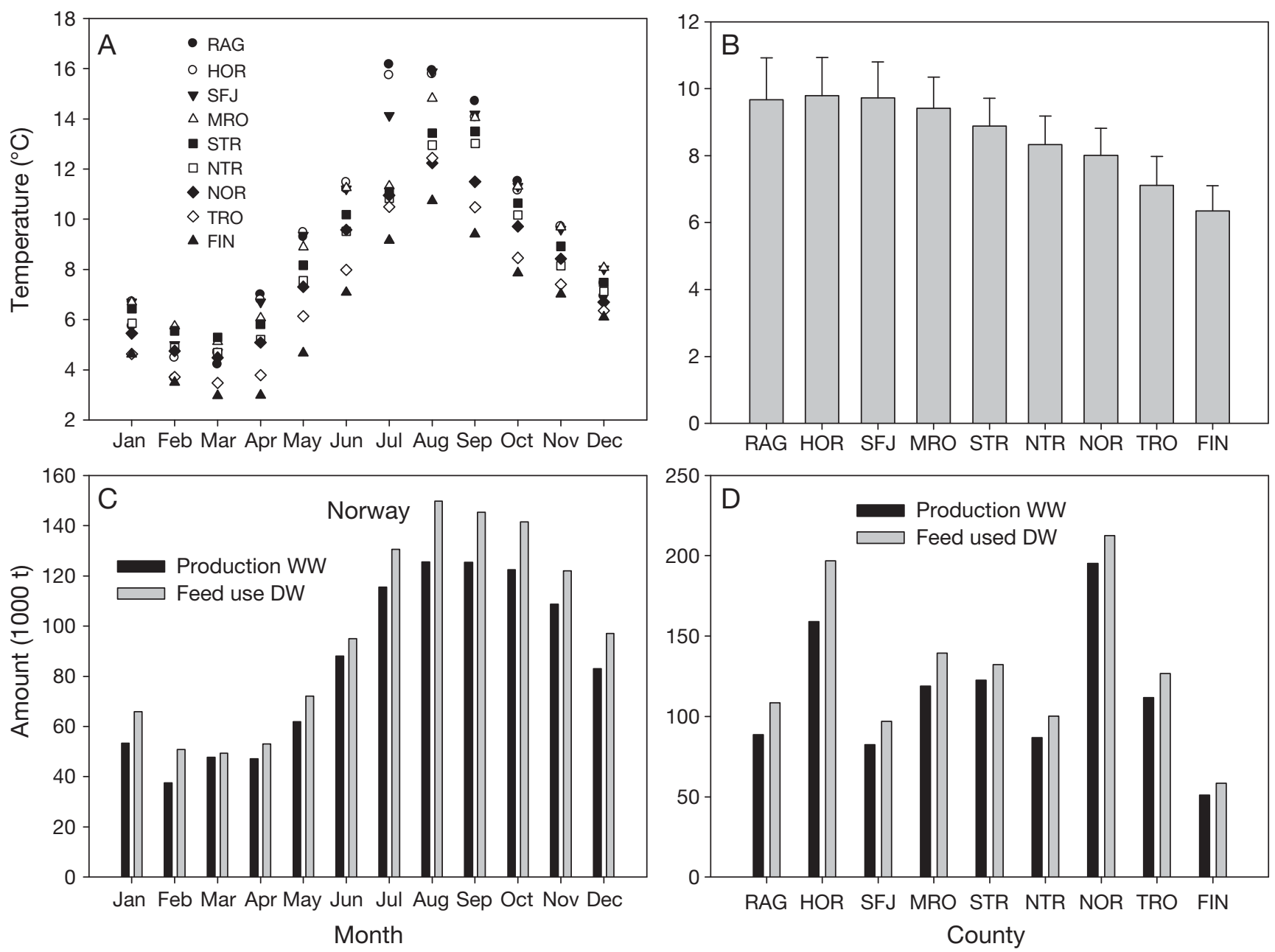

Fig. 2. Summary data on Norwegian salmon farms in 2009. (A) Monthly and (B) annual average surface water (0-15 m depth) temperature $\left({ }^{\circ} \mathrm{C}\right)$, by county. (C) Monthly total salmon production (t wet weight, WW) and total feed supplied (t dry weight, DW), and (D) annual salmon production feed supplied by county, based on Norwegian Fish Farmer Association (FHL) statistics. Counties are listed from south to north: top to bottom in (A), left to right in (B) and (D). RAG: Rogaland and Agder; HOR: Hordaland; SFJ: Sogn and Fjordane; MRO: Møre and Romsdal; STR: Sør-Trøndelag; NTR: Nord-Trøndelag; NOR: Nordland; TRO: Troms; FIN: Finnmark

statistically significant for $\mathrm{GE}_{\mathrm{C}}$ and $\mathrm{GE}_{\mathrm{p}}(\mathrm{p}<0.05)$, but not for $\mathrm{GE}_{N}(\mathrm{p}>0.05)$. The average $\mathrm{GE}_{\mathrm{C}}, \mathrm{GE}_{\mathrm{N}}$ and $\mathrm{GE}_{\mathrm{P}}$ values for all counties were $0.31 \pm 0.01,0.39 \pm$ 0.01 , and $0.31 \pm 0.01$, respectively. This means that $31 \pm 1 \%, 39 \pm 1 \%$ and $31 \pm 1 \%$ of the consumed $\mathrm{C}, \mathrm{N}$ and $\mathrm{P}$, respectively, were retained in fish biomass. $\mathrm{GE}_{\mathrm{N}}$ was higher than $\mathrm{GE}_{\mathrm{C}}$ and $\mathrm{GE}_{\mathrm{P}}$, indicating that a lower proportion of consumed $\mathrm{N}$ than of $\mathrm{C}$ and $\mathrm{P}$ was released through defecation and excretion (or respiration).

\section{Release rates of $\mathrm{C}, \mathrm{N}$ and $\mathrm{P}$ components}

The release rate of organic and inorganic $\mathrm{C}, \mathrm{N}$ and $\mathrm{P}$ components followed the same trend and showed a pronounced pattern of variation over the year (Fig. 4A-C), as did feed use and salmon production (Fig. 2C). The release rate of particulate, dissolved organic and dissolved inorganic wastes was highest in August with less than half of the maximum during the January-May period.

The model predictions were that the majority of the $\mathrm{C}$ and $\mathrm{N}$ waste from salmon farms was as respired $\mathrm{CO}_{2}$ and excreted DIN, respectively, whereas the majority of the $\mathrm{P}$ waste was particulate. There was accordingly a higher proportion of feed $\mathrm{C}$ and $\mathrm{N}$ than of feed $\mathrm{P}$ released as inorganic molecules. Correspondingly, the fraction of particulate $\mathrm{C}$ and $\mathrm{N}$ released was lower than the fraction of particulate P (Fig. 4A-C).

The average DIN:DIP ratio of the waste over the year (Fig. 4D) was $14.7 \pm 0.22$, well above the Red- 

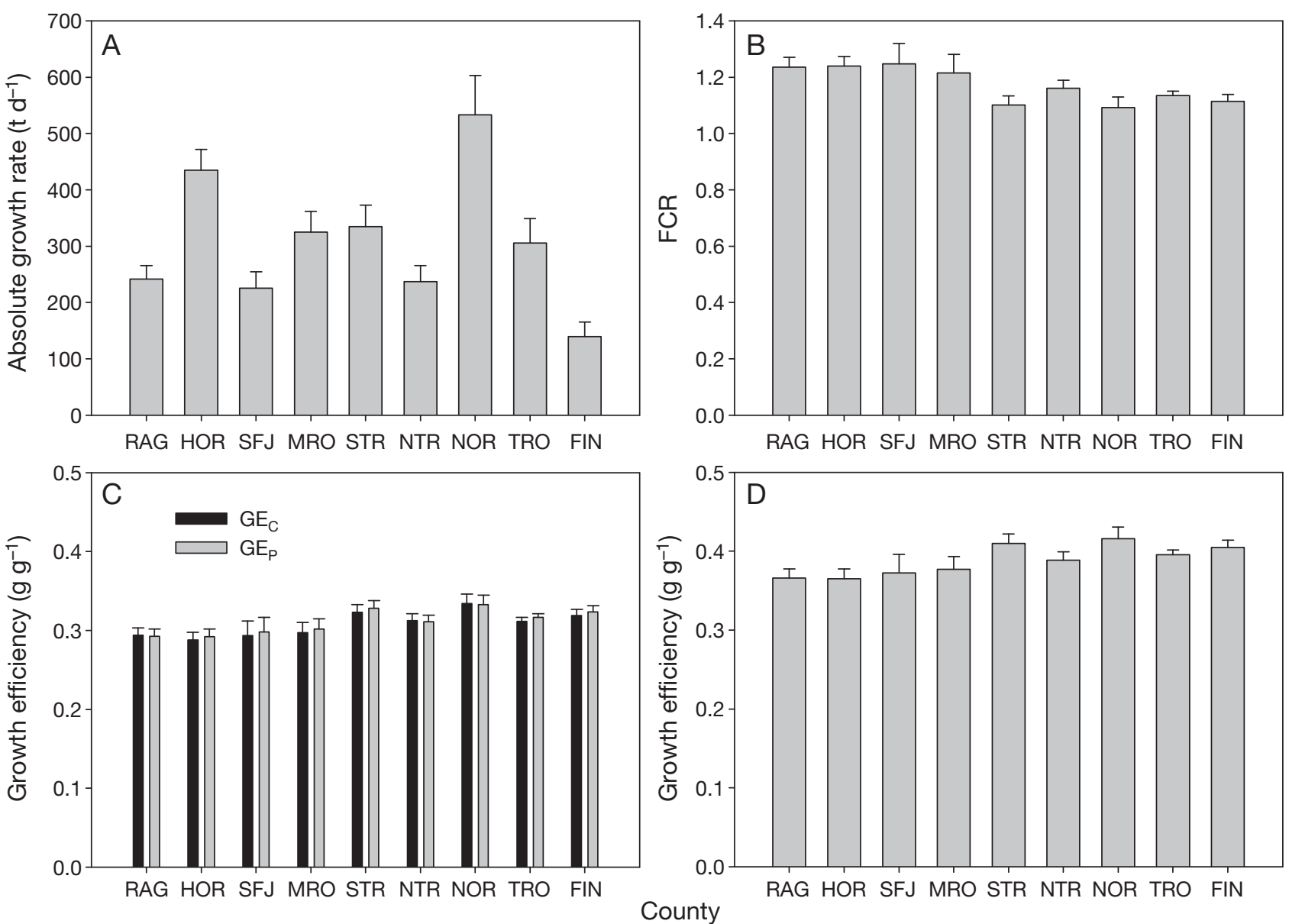

Fig. 3. Mass balance indices for Norwegian salmon farms, by county, 2009. (A) Absolute growth rate for salmon (mean \pm SE; $\left.\mathrm{t} \mathrm{d}^{-1}\right)$; (B) feed conversion ratio (FCR, dry weight feed per wet weight of fish produced). Growth efficiency (GE, $g$ produced per $g$ consumed, mean $+\mathrm{SE})$ of $(\mathrm{C})$ carbon $\left(\mathrm{GE}_{\mathrm{C}}\right)$, phosphorus $\left(\mathrm{GE}_{\mathrm{P}}\right)$ and $(\mathrm{D})$ nitrogen $\left(\mathrm{GE}_{\mathrm{N}}\right)$. Counties are listed from south to north, left to right; see Fig. 2 legend for full names of counties

field ratio of 7.2, suggesting that DIN was in excess of phytoplankton requirements relative to DIP. The model predicted a much lower and constant mean $\mathrm{N}$ :P ratio of 2.0 for both dissolved organic and for particulate organic waste. The average N:P ratio of total waste over the year was $5.4 \pm 0.02$, not far from the Redfield ratio, but with $\mathrm{P}$ in excess.

\section{Annual C, N and P mass balance of salmon farming}

The total input of $\mathrm{C}, \mathrm{N}$ and $\mathrm{P}$ (DW) through feeding in 2009 was 574 000, 81000 and 13500 t, respectively, and total salmon production was $1.02 \times 10^{6} \mathrm{t}$. Of the total input of feed, 70, 62 and $70 \% \mathrm{C}, \mathrm{N}$ and $\mathrm{P}$, respectively, were released back to the environment as inorganic and organic waste, corresponding to 397, 50 and $9.3 \mathrm{~kg} \mathrm{C}, \mathrm{N}$ and $\mathrm{P}$, respectively, $\mathrm{t}^{-1} \mathrm{WW}$ of fish produced.

The carbon mass balance showed that $48 \%$ of total feed $\mathrm{C}$ was respired by the fish, 19\% was released through defecation and 30\% was used for growth (Fig. 5A). Approximately $3 \%$ of the total feed input was resuspended from particles and became DOC.

The nitrogen mass balance (Fig. 5B) indicated that $38 \%$ of total feed $\mathrm{N}$ was incorporated and harvested as fish biomass, $45 \%$ was lost as DIN and $15 \%$ was released as PON. Approximately $3 \%$ of the total feed $\mathrm{N}$ was resuspended into the water as DON from particles, thus adding to the DON pool.

Of the total feed $\mathrm{P}, 44 \%$ of the input was released as POP, 30\% was retained in fish, and 18\% was lost as DIP. Approximately $8 \%$ of the total feed used was resuspended from particles to form DOP (Fig. 5C).

\section{Analysis of model sensitivity}

The model predictions depend on the input values of coefficients and variables, and Fig. 6 shows the effects of varying the fraction of feed losses (Fig. 6A,B), as- 

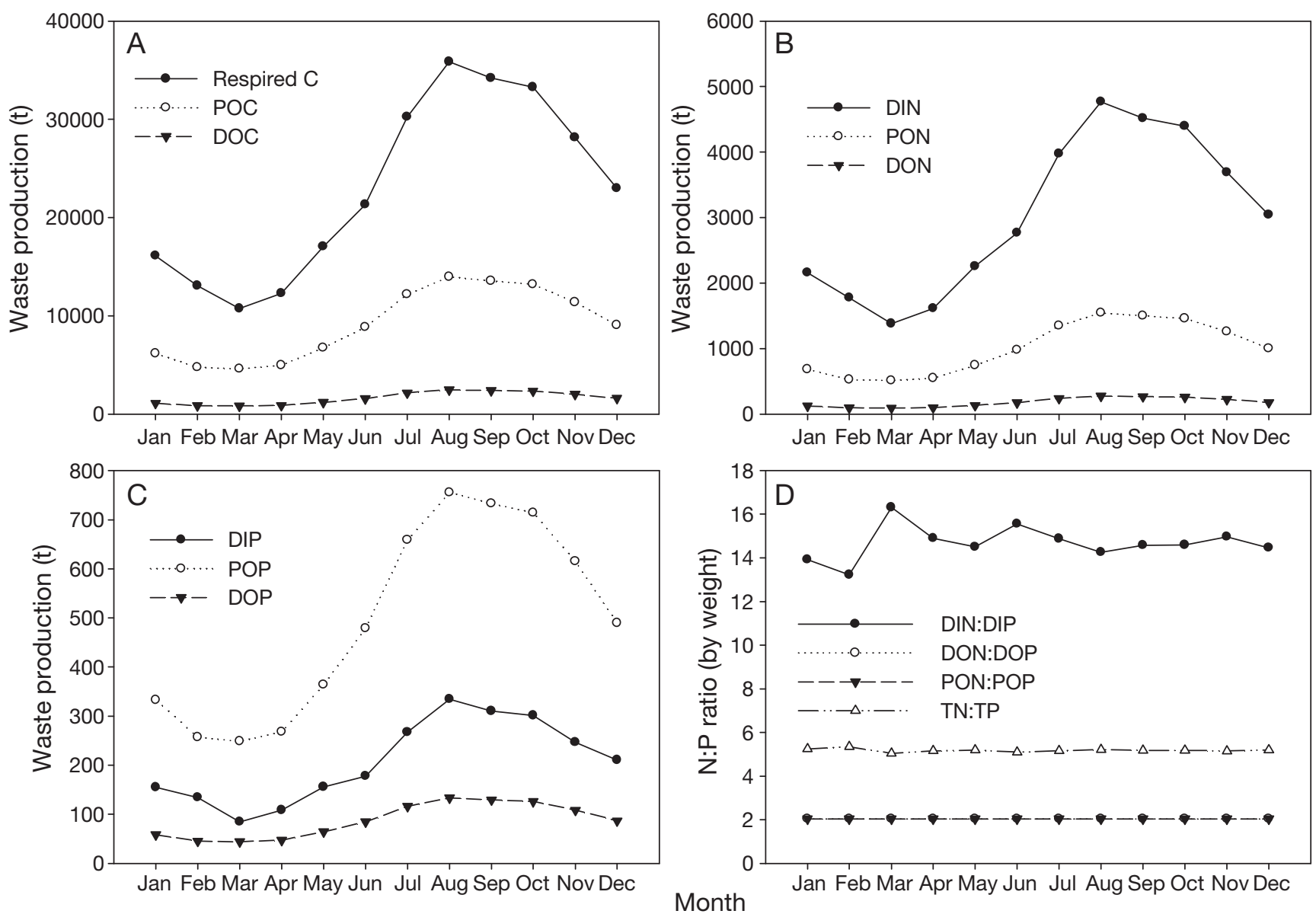

Fig. 4. Seasonal variation in $\mathrm{C}, \mathrm{N}$ and $\mathrm{P}$ release rates $\left(\mathrm{t} \mathrm{mo}^{-1}\right)$ and $\mathrm{N}: \mathrm{P}$ ratios for nutrient components released from Norwegian salmon aquaculture in 2009. (A) respired $\mathrm{CO}_{2}$, POC and DOC $;$ (B) DIN, PON and DON release; (C) DIP, DOP and POP release; (D) N:P ratios for different nutrient components. Note that DON:DOP and PON:POP ratio values overlap. TN, TP: total N and P, respectively; see Fig. 1 legend for other abbreviations

sumed to be $3 \%$ in the above calculations, and the $\mathrm{AE}$ (digestibility) of N (Fig. 6C) and P components (Fig. $6 \mathrm{D})$ in the feed, which were assumed to be 85 and $50 \%$, respectively, in the above calculations.

An increase in the loss of feed caused a decrease in percentage excretion of both DIN and DIP, and a similar increase in the percentage of combined organic waste. A minor variability in the feed loss from 0 to $5 \%$ did not cause major differences to model predictions.

A simulated variation in $\mathrm{AE}_{\mathrm{N}}$ and $\mathrm{AE}_{\mathrm{P}}$ affected the ratio of inorganic excretion to organic particulate defecation. The default value of $85 \%$ for $\mathrm{AE}_{\mathrm{N}}$ used in the above calculations is believed to be fairly accurate (Berge et al. 1999, Opstvedt et al. 2003, Azevedo et al. 2011), but the value of $A_{P}$ is more uncertain, partly because of the wide variety of molecular P species that are incorporated in pellet feeds with a high agricultural product content (Cho \& Bureau 2001,
Hua \& Bureau 2006, Azevedo et al. 2011). The difference in the ratios of DIN:DIP and PON:POP (Fig. 4D) mainly originated in the lower $\mathrm{AE}_{\mathrm{P}}$ value used in the calculations.

\section{Production potential of salmon-driven IMTA}

There is no accepted method for determining the proportion of dissolved inorganic and particulate organic aquaculture waste that can be used by co-cultured macroalgae and blue mussels, respectively, in open-water IMTA systems. Table 2 sets out the estimated potential of blue mussel wet flesh weight (WFW) and seaweed WW, and the area needed for that seaweed cultivation for the different counties (see 'Materials and methods'). The estimated potentials for the counties were closely related to the amount of feed used and fish produced. HOR showed the 

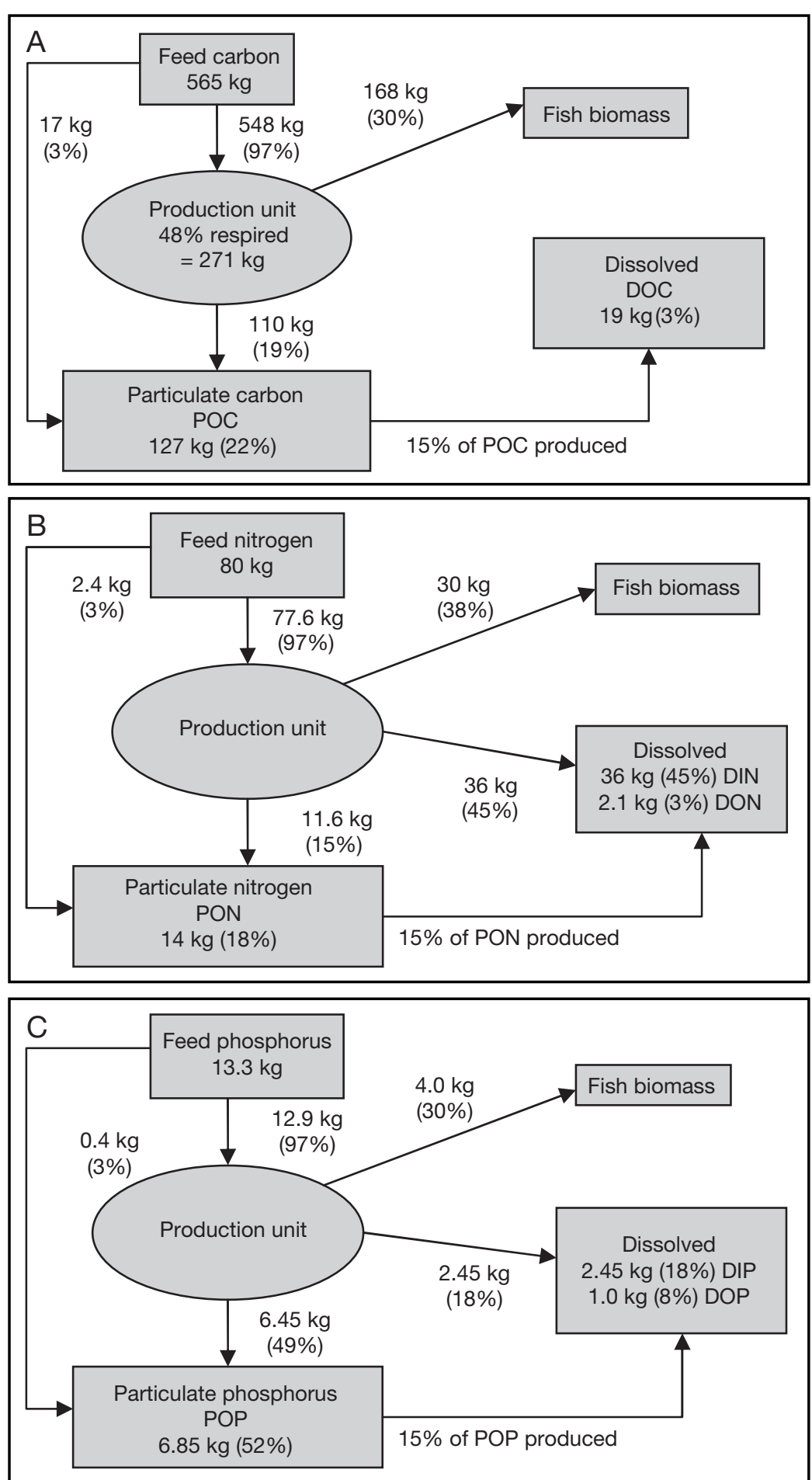

Fig. 5. Annual nutrient fluxes $\left(\mathrm{kg}[\mathrm{t} \text { produced } \times \mathrm{yr}]^{-1}\right)$ and components $\left(\mathrm{kg} \mathrm{t}^{-1}\right.$ produced) for Norwegian salmon farming in 2009: (A) C, (B) $\mathrm{N}$ and (C) $\mathrm{P}$

highest potential for production of seaweed based on wastes from salmon farming, whereas NOR showed the highest potential for blue mussels. The lowest production potential was found in FIN. The potential seaweed biomass (WW) for the whole country was in the range of $577 \times 10^{3}$ to $1730 \times 10^{3} \mathrm{t} \mathrm{yr}^{-1}$, while the potential mussel biomass (WW) was in the range of $7.2 \times 10^{3}$ to $22 \times 10^{3} \mathrm{t} \mathrm{yr}^{-1}$. The total DIN released from Norwegian salmon farming (not shown) corresponds to a seaweed production of around $5.8 \times$

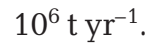

It is noteworthy that the potential for seaweed production was far higher than the potential for mussels. This is primarily a result of a smaller initial available resource and higher metabolic losses for mussels than for seaweeds. The area needed for seaweed cultivation for different counties followed the same trend as the potential seaweed biomass, and ranged from 4 to $44 \mathrm{~km}^{2}$ for individual counties and from 82 to $247 \mathrm{~km}^{2}$ for the country as a whole.

It is important to emphasize that the process of deriving production potential did not reveal accurate values that can be used for more detailed planning; however, it provides a preliminary estimation of the potential of IMTA driven by salmon farming in Norway. The fractions of wastes that can be acquired by seaweed and mussels are very uncertain, but the higher potential for seaweed than for mussels in salmon-driven IMTA, and the fact that seaweed cultivation requires a moderate area for growth, are both fairly robust conclusions.

\section{Loading rate of nutrients}

The potential impact on pelagic ecosystems of the inorganic nutrients excreted by farmed fish depends on the water volume to which these nutrients are drained. Table 3 summarizes our estimates of the volumetric loading rates of inorganic nutrients released from salmon farms by county in 2009 (see 'Materials and methods'). The annual loading rate from aquaculture decreased steadily from the southern to the northern counties, with annual values ranging from 10 to $146 \mathrm{mg} \mathrm{DIN} \mathrm{m}^{-3}$ $\mathrm{yr}^{-1}$ and 0.6 to $11 \mathrm{mg}$ DIP $\mathrm{m}^{-3} \mathrm{yr}^{-1}$. 

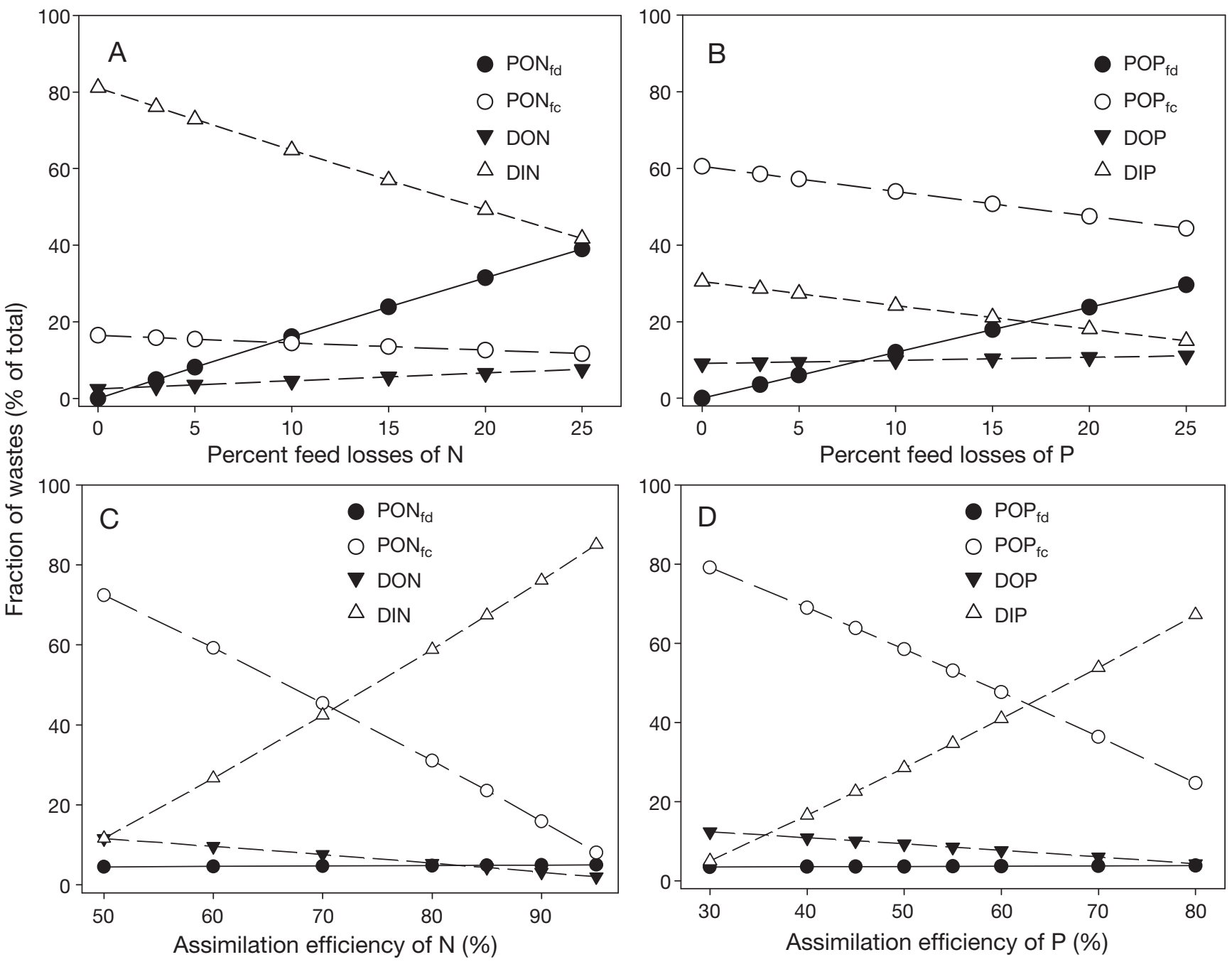

Fig. 6. Relative fractions of nitrogen $(\mathrm{N})$ and phosphorus $(\mathrm{P})$ waste components as a function of feed loss: (A) N, (B) P, and as a function of the assimilation efficiency of (C) $N$ and (D) P. fc: faecal origin; fd: origin from feed; see Fig. 1 legend for other abbreviations

Table 2. Potential of Norwegian aquaculture for integrated multi-trophic aquaculture (IMTA). County-level breakdown of dissolved inorganic nitrogen (DIN) and particulate organic carbon (POC) available for assimilation by seaweed and blue mussels, respectively (assumed to be 10-30\% of total DIN and 0.6-1.8\% of total POC; see 'Materials and methods'), potential seaweed and blue mussel production, and the area needed for potential seaweed production. See Fig. 2 legend for full names of counties. WW: wet weight; WFW: wet flesh weight

\begin{tabular}{|lcrcrr|}
\hline County & $\begin{array}{c}\text { DIN } \\
(\mathrm{t})\end{array}$ & $\begin{array}{c}\text { POC } \\
\mathrm{t})\end{array}$ & $\begin{array}{c}\text { Potential seaweed biomass } \\
\text { based on DIN (t WW) }\end{array}$ & $\begin{array}{c}\text { Potential blue mussel biomass } \\
\text { based on POC (t WFW) }\end{array}$ & $\begin{array}{c}\text { Area needed for potential } \\
\text { seaweed cultivation }\left(\mathrm{km}^{2}\right)\end{array}$ \\
\hline RAG & $350-1060$ & $60-180$ & $56000-168000$ & $660-1990$ & $8-25$ \\
HOR & $650-1940$ & $110-330$ & $102000-307000$ & $1200-3610$ & $15-44$ \\
SFJ & $310-920$ & $50-160$ & $49000-146000$ & $590-1780$ & $7-21$ \\
MRO & $440-1310$ & $80-230$ & $69000-208000$ & $850-2560$ & $10-30$ \\
STR & $390-1160$ & $70-220$ & $61000-184000$ & $810-2430$ & $9-26$ \\
NTR & $310-930$ & $60-170$ & $49000-148000$ & $610-1840$ & $7-21$ \\
NOR & $630-1880$ & $120-360$ & $99000-298000$ & $780-23300$ & $14-43$ \\
TRO & $390-1160$ & $70-210$ & $61000-184000$ & $360-1070$ & $9-26$ \\
FIN & $180-540$ & $30-100$ & $29000-86000$ & $7200-22000$ & $4-12$ \\
Total & & & $577000-1730000$ & & $82-247$ \\
\hline
\end{tabular}


Table 3. County-level recipient volumes and corresponding volumetric loading rates of dissolved inorganic nitrogen (DIN) and dissolved inorganic phosphorus (DIP) released by Norwegian salmon farms in 2009 , showing annual totals and volumetric loading rates ( $\mu \mathrm{g} \mathrm{m}^{-3} \mathrm{~d}^{-1}$ ) for the summer-autumn (June-November) and winter-spring (December-May) periods. See Fig. 2 legend for full names of counties

\begin{tabular}{|c|c|c|c|c|c|c|c|c|c|c|}
\hline County & $\begin{array}{c}\text { Area } \\
\text { inside } \\
\text { baseline } \\
\left(\mathrm{km}^{2}\right)\end{array}$ & $\begin{array}{l}\text { Volume } \\
\text { inside } \\
\text { baseline } \\
\left(\mathrm{km}^{3}\right)\end{array}$ & $\begin{array}{c}\text { DIN } \\
\left({\left.\mathrm{t} \mathrm{yr}^{-1}\right)}^{-1}\right.\end{array}$ & $\begin{array}{c}\text { DIP } \\
\left({\left.\mathrm{t} \mathrm{yr}^{-1}\right)}^{-1}\right.\end{array}$ & $\begin{array}{c}\text { DIN } \\
\left(\mathrm{mg} \mathrm{m}^{-3} \mathrm{yr}^{-1}\right)\end{array}$ & $\begin{array}{c}\text { DIP } \\
\left(\mathrm{mg} \mathrm{m}^{-3} \mathrm{yr}^{-1}\right)\end{array}$ & $\begin{array}{c}{ }_{\left(\mu \mathrm{g} \mathrm{m}^{-3} \mathrm{~d}^{-1}\right)} \text { DIN } \\
\text { Summer-autumn } \\
(\text { Jun-Nov) }\end{array}$ & $\begin{array}{l}\mathrm{N} \\
\left(\mu \mathrm{g} \mathrm{m}^{-3} \mathrm{~d}^{-1}\right) \\
\text { Winter-spring } \\
\text { (Dec-May) }\end{array}$ & $\begin{array}{c}\left(\mu \mathrm{g} \mathrm{m}^{-3} \mathrm{~d}^{-1}\right) \\
\text { SiP } \\
\text { (Jummer-Nov) }\end{array}$ & $\begin{array}{l}\left.\mu \mathrm{g} \mathrm{m}^{-3} \mathrm{~d}^{-1}\right) \\
\text { Winter-spring } \\
\text { (Dec-May) }\end{array}$ \\
\hline RAG & 1710 & 26 & 3532 & 252 & 138 & 10 & 471 & 283 & 34 & 20 \\
\hline HOR & 2940 & 44 & 6449 & 464 & 146 & 11 & 501 & 300 & 36 & 22 \\
\hline SFJ & 3490 & 52 & 3065 & 213 & 59 & 4.1 & 196 & 125 & 13 & 9 \\
\hline MRO & 5220 & 78 & 4373 & 303 & 56 & 3.9 & 197 & 109 & 13 & 7.8 \\
\hline STR & 6380 & 96 & 3862 & 249 & 40 & 2.6 & 140 & 81 & 9 & 5.5 \\
\hline NTR & 4660 & 70 & 3113 & 213 & 45 & 3.1 & 166 & 78 & 11 & 5.4 \\
\hline NOR & 30670 & 460 & 6263 & 407 & 14 & 0.9 & 53 & 22 & 3.5 & 1.4 \\
\hline TRO & 9900 & 149 & 3872 & 261 & 26 & 1.8 & 102 & 41 & 6.9 & 2.7 \\
\hline FIN & 12680 & 190 & 1797 & 122 & 9.5 & 0.6 & 40 & 12 & 2.8 & 0.8 \\
\hline
\end{tabular}

Approximately 61 to $78 \%(67 \pm 1.8 \%)$ of DIN and 62 to $78 \%(66 \pm 2.2 \%)$ of DIP were released in the summer-autumn period in 2009 (June-November). In the summer-autumn period, the average daily loading rates varied between 40 and $501 \mu \mathrm{g}$ DIN m ${ }^{-3} \mathrm{~d}^{-1}$ and between 2.8 and $36 \mu \mathrm{g}$ DIP m${ }^{-3} \mathrm{~d}^{-1}$. In the winter-spring period, the county-level nutrient loading rates varied between 12 and $300 \mu \mathrm{g} \mathrm{N} \mathrm{m}^{-3} \mathrm{~d}^{-1}$ and between 0.8 and $22 \mu \mathrm{g} \mathrm{P} \mathrm{m}{ }^{-3} \mathrm{~d}^{-1}$. Nutrient loading rates related to sea surface area $\left(\mathrm{m}^{-2}\right)$ instead of volume were 15 times higher than the volumetric rates.

\section{DISCUSSION}

Intensive salmon aquaculture generates dissolved and particulate nutrient waste to the surrounding benthic and pelagic ecosystems (Mente et al. 2006), and considerable attention has been paid to the potential influence that organic matter and nutrients (biogenic waste) released from fish farming may have on coastal ecosystems (Sanz-Lázaro \& Marín 2011). One main purpose of the present study was to evaluate the potential for IMTA driven by waste products from salmon farming in Norway. The different biogenic waste components are potential food resources for different farmed organisms at lower trophic levels, such as seaweed and mussels, and knowledge about both release rate and fate of biogenic waste components is paramount for deducing both IMTA potential and the effects that the waste may have on the ecosystems of receiving waters. IMTA is in fact a means to add value to investments in feed for aquaculture while simultaneously contributing to mitigation of potential negative impacts of fish farming on the environment.
Estimating the release rate of biogenic $\mathrm{C}, \mathrm{N}$ and $\mathrm{P}$ waste from fish farms is important in the evaluation of the potential effects that salmon aquaculture may have on the environment and the potential of salmon-driven IMTA. We used a simple and transparent method to estimate the release rate of waste, which we suggest is also reasonably robust and flexible. The estimates of total release rate of $\mathrm{C}, \mathrm{N}$ and $\mathrm{P}$ are dependent on statistical information about the use of feed and production of salmon, together with easily measurable coefficients describing the elemental $\mathrm{C}, \mathrm{N}$ and $\mathrm{P}$ composition of feed and fish. The relative distribution of organic waste and dissolved inorganic waste is additionally dependent on the digestibility of $\mathrm{C}, \mathrm{N}$ and $\mathrm{P}$ components of the feed and the rate of feed loss during feeding.

A fundamental question to be considered in using the mass balance method is whether or not the use of feed and the production of fish are relatively stable from month to month. Feed is used more or less continuously over time whereas fish production may to some extent be related to fish harvesting at the end of the life cycle. The events associated with harvesting might logically be more temporary and not as continuous over time as feeding. We found, however, that feeding and production (harvesting and biomass increment) are well balanced when FCR was calculated from month to month at the scale of a county (data not shown). The FCR values among counties were also stable (Fig. 3B).

The feed input is the most important input variable in the model. If the approximate value of FCR is adequately known - in the present case it might be assumed to be equal to the national average FCR for the Norwegian salmon industry - fish production can be estimated based on data for feed use divided 
by the average FCR. This method is also appropriate for application to single fish farms where use of feed and harvesting are more variable and out of phase. In the present case, fish production estimates generated for single farms could use the average FCR for the county. However, calculations should always be made with care, and this procedure is only applicable for farms that apply a standardized pellet feed and modern feeding technology. Variable feed composition and digestibility should be reflected in the input coefficients used in the calculations (Table 1), and the coefficients may even be directly measured if necessary.

\section{$\mathrm{C}, \mathrm{N}$ and $\mathrm{P}$ release rates}

Our calculations revealed that as much as 70, 62 and $70 \%$ of the total $\mathrm{C}, \mathrm{N}$ and $\mathrm{P}$, respectively, in feed input were lost to the environment in 2009 (Fig. 5A-C). This implies total annual C, N and P discharges of about 404000,50600 and $9400 \mathrm{t}$ of $\mathrm{C}, \mathrm{N}$ and $\mathrm{P}$, respectively. The monthly nutrient release rates over the year followed the same trend as feed use and fish production, as was also found in earlier studies (Davies 2000, Islam 2005). Approximately $67 \%$ of the total biogenic waste was released in the summer-autumn period (June-November) (Table 3). Moreover, of the total $\mathrm{C}$ input to the fish farms, $48 \%$ was respired as $\mathrm{CO}_{2}$ and $19 \%$ was lost as POC (Fig. 5A). The majority of feed $\mathrm{N}$ consumed was excreted as DIN (45\%), corresponding to $36 \mathrm{~kg}$ DIN $\mathrm{t}^{-1}$ of salmon produced (Fig. 5B), in agreement with the DIN release rate by salmon farms in Scotland (35 to $45 \mathrm{~kg} \mathrm{~N} \mathrm{t}^{-1}$ fish produced; Davies 2000). The majority of feed $\mathrm{P}$ was lost as particles $(44 \%$, net POP) whereas $18 \%$ was released as DIP, corresponding to $2.45 \mathrm{~kg}$ DIP $\mathrm{t}^{-1}$ of salmon produced (Fig. 5C).

Our estimates of nutrient release rates were similar to values obtained in some previous studies (Penczak et al. 1982, Phillips et al. 1985, Hall 1990, á Norði et al. 2011, Azevedo et al. 2011), but were lower than values reported by others (Gowen et al. 1985, Holby \& Hall 1991, Hall et al. 1992, Chen 2000, Pérez 2002, Islam 2005, Corner et al. 2006). The selected values of input coefficients (Table 1) and other assumptions made affected the outcome of the predictions. As pointed out above, the stoichiometric $\mathrm{C}, \mathrm{N}$ and $\mathrm{P}$ coefficients for feed and fish, the rate of feed loss and the digestibility of $\mathrm{N}$ and $\mathrm{P}$ components of the feed all affect the estimated release rates of the waste components in our calculations.
To illustrate the dependence of the predictions on a variable data input, we carried out some simple analysis of sensitivity of model predictions, following varying rate of feed loss and digestibility of $\mathrm{N}$ and $\mathrm{P}$ components of the feed. The total organic $\mathrm{C}$ waste $(\mathrm{POC}+\mathrm{DOC})$ increases and the release of DIC through respiration decreases for higher rates of feed loss, but the total release of $\mathrm{N}$ and $\mathrm{P}$ remains constant and independent of the rate of feed loss (Fig. 6A,B). The particulate $\mathrm{N}$ and $\mathrm{P}$ fraction of total loss, however, increases while the fraction of inorganic $\mathrm{N}$ and $\mathrm{P}$ decreases as feed loss increases (Azevedo et al. 2011). Our calculations revealed a similar release rate of DIN and total organic $\mathrm{N}$ for feed loss of approximately $15 \%$ while DIP was released in lower quantities than total organic P (POP + DOP) for all values of feed losses (Azevedo et al. 2011).

A similar pattern of variation was also apparent for a variable digestibility of $\mathrm{N}$ and $\mathrm{P}$ components of the feed (Fig 6C,D). Reduced digestibility of $\mathrm{N}$ and $\mathrm{P}$ resulted in reduced relative release rates of DIN and DIP, respectively, and a similar increase in the release rate of total organic $\mathrm{N}$ and $\mathrm{P}$. Because feed $\mathrm{N}$ is mainly associated with proteins, we assumed that $85 \%$ of the $\mathrm{N}$ is digested by fish, this being a normal value for fish feed protein digestibility, as declared by feed manufacturers (T. Lea, Skretting AS pers. comm.). The assumptions for $\mathrm{N}$ are fairly robust, whereas the digestibility of $\mathrm{P}$ components in salmonids feed is much more uncertain, partly because of the high diversity of molecular $\mathrm{P}$ species in the feed (Cho \& Bureau 2001, Hua \& Bureau 2006). Previous studies that reported the digestibility coefficients for $\mathrm{P}$ in rainbow trout have varied in the range of 0.43 to 0.71 , depending on the methods used (Vandenberg \& De La Noüe 2001, Bureau et al. 2003, Azevedo et al. 2011, Dalsgaard \& Pedersen 2011). We assumed that $50 \%$ of the $\mathrm{P}$ in the feed is assimilated in salmon (Reid et al. 2009), to obtain approximate estimations of the released fractions of DIP and POP+DOP waste.

\section{Evaluation of IMTA potential}

Several macroalgae and filter or deposit feeding organisms have the potential to incorporate and utilize specific biogenic wastes from fish farms (Troell et al. 1997, Troell \& Norberg 1998, Whitmarsh et al. 2006, Marinho-Soriano et al. 2009, Redmond et al. 2010, Abreu et al. 2011). There is, however, no general concept developed for evaluating appropriate plant and animal species or for estimating the specific IMTA potential of that species in a given aqua- 
culture system and environment. As a first approach, and to illustrate the potential, we assumed that 10 to $30 \%$ of the total DIN and 0.6 to $1.8 \%$ of the total POC from salmon farms could, using appropriate technologies, be made available for cultured seaweed and blue mussels. Our exercise demonstrated a far higher potential for seaweed production, corresponding (by weight) to $60-170 \%$ of Norwegian salmon production, than for mussel, corresponding to $0.7-2.2 \%$ of national salmon production. The potential yield of mussels, based directly on small particles of feed and faeces, was relatively low, and would still be low even if all the small particles were made available for mussels. This suggested that particulate waste from salmon farming is less important than their natural food sources, even if the mussels are cultured close to the salmon farm.

As mentioned, these estimates are uncertain because many factors, such as the physical arrangement of the IMTA system, water currents, nutrient concentrations, light and temperature conditions, stocking densities, bio-fouling, and others, can limit nutrient uptake in seaweed and food consumption in blue mussels (Troell et al. 2003). In addition, the $\mathrm{N}$ and dry matter content in seaweed co-cultured with fish farm effluents can vary quite pronouncedly (Carmona et al. 2001, Porrello et al. 2003, Schuenhoff et al. 2003, Yang et al. 2006), which would affect our estimated potentials.

If, as assumed above, 10 to $30 \%$ of the released DIN is assimilated in macroalgae, it follows that 70 to $90 \%$ can become assimilated in phytoplankton, corresponding to $25 \times 10^{3}$ to $33 \times 10^{3}$ t of DIN (Table 3). This DIN will be widely spread by hydrodynamic forces and diluted to low levels, but can nevertheless support a realized phytoplankton biomass in the range of $1.3 \times 10^{6}$ to $1.6 \times 10^{6} \mathrm{t}$ fresh weight (assuming a WW:N ratio of 50 ), which can in turn support a fresh biomass production of approximately $0.3 \times 10^{6} \mathrm{t}$ of blue mussels, far higher than that supported by particulate waste (Table 2). However, this DIN resource is difficult to capture in IMTA, and will normally only stimulate the natural food webs.

Although the potential of producing co-cultured species in an open-water salmon-driven IMTA system cannot be accurately determined, our exercise was able to give a general idea of the economic potential of introducing an IMTA system. Practical testing of systems and locations are needed to draw final conclusions about the potential, but preliminary estimates such as ours may motivate that step and contribute to the growing interest in IMTA, as an ecosystem-based approach that can sustain added value in aquaculture production, while mitigating waste output (Reid et al. 2009).

\section{Evaluation of nutrient loading rates}

The probability of harmful eutrophication in coastal waters should be evaluated based on estimation of the volumetric nutrient loading rate of the water system, defined as mass of nutrient input per water volume and time. A main modifying factor for ecological impacts is the capacity of the recipient waters to assimilate the nutrients, which is strongly related to water retention time and hydrodynamics (Yokoyama et al. 2004). This principle is very well established for freshwater systems, where the recipient volume and residence time of the water can be estimated relatively easily (Vollenweider 1976). No unique volume can be estimated for the receiving water masses for open coastal waters, but there is a need to define principles for doing so, in order to meet the requirements of developing and implementing an ecosystem-based management system for coastal waters (Tett 2008)

In Norway, county administrations will most likely become responsible for managing the national marine environment and resources, and we have estimated the volume for euphotic waters (mixed layers, 0 to $15 \mathrm{~m}$ depth) of the separate counties to a fairly good level of accuracy (Table 3). We suggest that these county-level water regions can be defined as the receiving ecosystems. From an ecological point of view, this pragmatic definition is as good as any other definition of the receiving ecosystem.

The ecological relevance of using a pragmatic county-level definition of receiving waters is a complex issue, but we suggest that the feasibility of this approach is mainly determined by the mixing efficiency of the euphotic water masses. Nutrients from most anthropogenic sources, among them aquaculture, are released from point sources. The suggested approach will work adequately and generate maximum values if the mixing time of the euphotic water that receives the point sources of nutrients is either faster or similar to the time needed for the organisms of the pelagic ecosystem to respond to an enhanced nutrient input. Phytoplankton will normally need 3 to $7 \mathrm{~d}$ to respond to a moderate increase in nutrient concentration, whereas crustacean zooplankton species may need $>10$ d (Buschmann et al. 2007, Olsen et al. 2007, 2011).

Water masses in relatively closed fjords may need a longer time for mixing, but it is also likely that some 
outer and more exposed coastal waters may become well mixed within $\sim 1 \mathrm{wk}$. The receiving water masses of exposed coastal waters will then exchange with coastal water outside the baseline from the very beginning, supporting the suggestion that estimated loading rates can represent a maximum value if mixing is fast, and a minimum if it is slower than 1 to $2 \mathrm{wk}$.

Three-dimensional hydrodynamic modelling may, at a later stage, support the estimation of mixing times needed for the different county-level water regions. Such information is relevant for appropriate localization of large fish farms and to minimize the ecological influence of nutrients as production further increases in the future (Tsagaraki et al. 2011).

Our exercise showed a gradual reduction in the volumetric loading rates of inorganic $\mathrm{N}$ and $\mathrm{P}$ from salmon farms from lower to higher latitudes along the Norwegian coast (Table 3), with lower $\mathrm{N}$ and $P$ release rates through winter-spring than through summer-autumn seasons (Fig. 4B,C). The daily volumetric loading rates of DIN, which generally limit phytoplankton production in Norwegian coastal waters during summer-autumn, were estimated to range from 40 to $501 \mu \mathrm{g} \mathrm{N} \mathrm{m}{ }^{-3} \mathrm{~d}^{-1}$ during June-November, with the lowest value for FIN and the highest for HOR (Table 3). The natural fertilization of nitrate (DIN) from deep water during the summer period (June-September) in central Norway was approximately $4 \mathrm{mg} \mathrm{N} \mathrm{m}^{-3} \mathrm{~d}^{-1}$ (Y. Olsen, O. Vadstein unpubl. data). This natural loading rate was 8 to 100 times higher than the DIN loading from aquaculture in the counties. Fertilization experiments (Olsen et al. unpubl., Vadstein et al. unpubl.) have also revealed that the pelagic ecosystem will not be negatively affected as long as the total anthropogenic supply of DIN does not exceed the natural supply rate to coastal waters by a factor of $>1.3$, suggesting that the current nutrient supply from aquaculture in the counties may be within safe limits.

\section{CONCLUSIONS}

The mass balance proposed in the present study is a reliable tool to estimate waste release rate on a national and regional scale, and this method is also appropriate for application to single fish farms. Our model demonstrated that 70,62 and $70 \%$ of $\mathrm{C}, \mathrm{N}$ and $\mathrm{P}$, respectively, of the total feed input were released into the environment, equivalent to 404000,50600 and 9400 t C, N and $\mathrm{P}$, respectively. Consequently, the waste emission of $\mathrm{C}, \mathrm{N}$ and $\mathrm{P}$, respectively, was 397, 50 and $9.3 \mathrm{~kg} \mathrm{t}^{-1}$ of fish produced, with total salmon production of $1.02 \times 10^{6} \mathrm{t}$. Some $48 \%$ of feed $\mathrm{C}$ was respired as $\mathrm{CO}_{2}, 45 \%$ of feed $\mathrm{N}$ excreted as DIN and $44 \%$ of feed $\mathrm{P}$ was released as solid waste. Our exercise of estimating a potential of IMTA driven by salmon farming demonstrated a far higher potential for seaweed production than for mussels. This was mostly because of smaller initial resource availability and higher metabolic losses for mussels than for seaweed. The daily volumetric loading rates of DIN from salmon farms were low compared to the natural loading rate of nitrate from deep water during the summer period (June-September) in central Norway, suggesting that the nutrient loading rate from aquaculture may remain within safe limits.

Acknowledgements. We thank the Norwegian Fish Farmer Association and J. A. Grøttum for access to their statistical material for county-level use of feed and salmon production in 2009. We also thank T. Lea in Skretting AS for access to the results of digestion assessments of feed, and Biomar AS for data on fish and feed stoichiometry.

\section{LITERATURE CITED}

Abreu MH, Pereira R, Yarish C, Buschmann AH, SousaPinto I (2011) IMTA with Gracilaria vermiculophylla: productivity and nutrient removal performance of the seaweed in a land-based pilot scale system. Aquaculture 312:77-87

Ackefors H, Enell M (1990) Discharge of nutrients from Swedish fish farming to adjacent sea areas. Ambio 19: 28-35

á Norði G, Glud RN, Gaard E, Simonsen K (2011) Environmental impacts of coastal fish farming: carbon and nitrogen budgets for trout farming in Kaldbaksfjorour (Faroe Islands). Mar Ecol Prog Ser 431:223-241

> Azevedo PA, Podemski CL, Hesslein RH, Kasian SEM, Findlay DL, Bureau DP (2011) Estimation of waste outputs by a rainbow trout cage farm using a nutritional approach and monitoring of lake water quality. Aquaculture 311: 175-186

> Barrington $\mathrm{K}$, Ridler N, Chopin $\mathrm{T}$, , Robinson S, Robinson B (2010) Social aspects of the sustainability of integrated multi-trophic aquaculture. Aquacult Int 18:201-211

> Berge GM, Grisdale-Helland B, Helland SJ (1999) Soy protein concentrate in diets for Atlantic halibut (Hippoglossus hippoglossus). Aquaculture 178:139-148

Beveridge MCM (1987) Cage aquaculture. Fishing News Books, Farnham

Bureau DP, Gunther SJ, Cho CY (2003) Chemical composition and preliminary theoretical estimates of waste outputs of rainbow trout reared in commercial cage culture operations in Ontario. N Am J Aquaculture 65:33-38

- Buschmann AH, Mora OA, Gómez P, Böttger M and others (1994) Gracilaria chilensis outdoor tank cultivation in Chile: use of land-based salmon culture effluents. Aquacult Eng 13:283-300

Buschmann AH, Troell M, Kautsky N, Kautsky L (1996) Integrated tank cultivation of salmonids and Gracilaria chilensis (Gracilariales, Rhodophyta). Hydrobiologia 326-327: $75-82$ 
Buschmann A, Costa-Pierce B, Cross S, Iriarte J, Olsen Y, Reid G (2007) Nutrient impacts of farmed Atlantic salmon (Salmo salar) on pelagic ecosystems and implications for carrying capacity. Report of the Technical Working Group (TWG) on nutrients and carrying capacity of the Salmon Aquaculture Dialogue. WWF, Washington DC

Carmona R, Kraemer GP, Zertuche JA, Chanes L, Chopin T, Neefus C, Yarish C (2001) Exploring Porphyra species for use as nitrogen scrubbers in integrated aquaculture. J Phycol 37:9-10

Chen YS (2000) Waste outputs and dispersion around marine fish cages and the implications for modelling. $\mathrm{PhD}$ thesis, University of Stirling

Chen YS, Beveridge MCM, Telfer TC, Roy WJ (2003) Nutrient leaching and settling rate characteristics of the faeces of Atlantic salmon (Salmo salar L.) and the implications for modelling of solid waste dispersion. J Appl Ichthyol 19:114-117 doi:10.1046/j.1439-0426.2003.00449.x

Cheshuk BW, Purser GJ, Quintana R (2003) Integrated open-water mussel (Mytilus planulatus) and Atlantic salmon (Salmo salar) culture in Tasmania, Australia. Aquaculture 218:357-378

Cho CY, Bureau DP (2001) A review of diet formulation strategies and feeding systems to reduce excretory and feed wastes in aquaculture. Aquacult Res 32:349-360

Chopin T, Buschmann AH, Halling C, Troell M and others (2001) Integrating seaweeds into marine aquaculture systems: a key toward sustainability. J Phycol 37: 975-986

Corner R, Brooker A, Telfer T, Ross L (2006) A fully integrated GIS-based model of particulate waste distribution from marine fish-cage sites. Aquaculture 258:299-311

Cromey CJ, Nickell TD, Black KD (2002) DEPOMOD-modelling the deposition and biological effects of waste solids from marine cage farms. Aquaculture 214:211-239

> Cromey CJ, Nickell TD, Treasurer J, Black KD, Inall M (2009) Modelling the impact of cod (Gadus morhua L.) farming in the marine environment-CODMOD. Aquaculture 289:42-53

> Dalsgaard J, Pedersen PB (2011) Solid and suspended/dissolved waste (N, P, O) from rainbow trout (Oncorynchus mykiss). Aquaculture 313:92-99

Davies IM (2000) Waste production by farmed Atlantic salmon (Salmo salar) in Scotland. ICES CM O:01

> Davies IA, Slaski RJ (2003) Waste production by farmed Atlantic halibut (Hippoglossus hippoglossus L.). Aquaculture 219:495-502

Elberizon IR, Kelly LA (1998) Empirical measurements of parameters critical to modelling benthic impacts of freshwater salmonid cage aquaculture. Aquacult Res 29: 669-677

Enell M (1995) Environmental-impact of nutrients from Nordic fish farming. Water Sci Technol 31:61-71

> Fan CL, Glibert PM, Burkholder JM (2003) Characterization of the affinity for nitrogen, uptake kinetics, and environmental relationships for Prorocentrum minimum in natural blooms and laboratory cultures. Harmful Algae 2: 283-299

Fang J, Sun H, Yan J, Kuang S, Li F, Newkirk G, Grant J (1996) Polyculture of scallop Chlamys farreri and kelp Laminaria japonica in Sungo Bay. Chin J Oceanology Limnol 14:322-329

FAO (2010) FAO yearbook: fishery and aquaculture statistics. 2008. Food and Agriculture Organization, Rome

Gillibrand PA, Gubbins MJ, Greathead C, Davies IM (2002) Scottish executive loctional guidelines for fish farming: predicted levels of nutrient enhancement and benthic impact. Scott Fish Res Rep 63/2002, Fisheries Research Services, Aberdeen

Gowen RJ, Bradburt NB, Brown JR (1985) The ecological impact of salmon farming in Scottish coastal waters: a preliminary appraisal. ICES CM F:35

Hall POJ, Anderson LG, Holby O, Kollberg S, Samuelsson M (1990) Chemical fluxes and mass balances in a marine fish cage farm. 1. Carbon. Mar Ecol Prog Ser 61:61-73

> Hall POJ, Holby O, Kollberg S, Samuelsson M (1992) Chemical fluxes and mass balances in a marine fish cage farm. IV. Nitrogen. Mar Ecol Prog Ser 89:81-91

Handå A (2012) Cultivation of mussels (Mytilus edulis): feed requirements, storage and integration with salmon (Salmo salar) farming. PhD thesis, Norwegian University of Science and Technology, Trondheim

> Holby O, Hall POJ (1991) Chemical fluxes and mass balances in a marine fish cage farm. II. Phosphorus. Mar Ecol Prog Ser 70:263-272

Hua K, Bureau DP (2006) Modelling digestible phosphorus content of salmonid fish feeds. Aquaculture 254:455-465

Islam MS (2005) Nitrogen and phosphorus budget in coastal and marine cage aquaculture and impacts of effluent loading on ecosystem: review and analysis towards model development. Mar Pollut Bull 50:48-61

> Kraemer GP, Carmona R, Chopin T, Neefus C, Tang XR, Yarish C (2004) Evaluation of the bioremediatory potential of several species of the red alga Porphyra using short-term measurements of nitrogen uptake as a rapid bioassay. J Appl Phycol 16:489-497

Li SF (1987) Energy structure and efficiency of a typical Chinese integrated fish farm. Aquaculture 65:105-118

MacDonald BA, Robinson SMC, Barrington KA (2011) Feeding activity of mussels (Mytilus edulis) held in the field at an integrated multi-trophic aquaculture (IMTA) site (Salmo salar) and exposed to fish food in the laboratory. Aquaculture 314:244-251

Marinho-Soriano E, Nunes SO, Carneiro MAA, Pereira DC (2009) Nutrients' removal from aquaculture wastewater using the macroalgae Gracilaria birdiae. Biomass Bioenergy 33:327-331

> Martínez-Aragón JF, Hernández I, Pérez-Llorens JL, Vázquez R, Vergara JJ (2002) Biofiltering efficiency in removal of dissolved nutrients by three species of estuarine macroalgae cultivated with sea bass (Dicentrarchus labrax) waste waters 1. Phosphate. J Appl Phycol 14: 365-374

> Mente E, Pierce GJ, Santos MB, Neofitou C (2006) Effect of feed and feeding in the culture of salmonids on the marine aquatic environment: a synthesis for European aquaculture. Aquacult Int 14:499-522

> Møhlenberg F, Riisgård HU (1978) Efficiency of particle retention in 13 species of suspension feeding bivalves. Ophelia 17:239-246

Navarrete-Mier F, Sanz-Lázaro C, Marín A (2010) Does bivalve mollusc polyculture reduce marine fin fish farming environmental impact? Aquaculture 306:101-107

Olsen Y, Olsen LM (2008) Environmental impact of aquaculture on coastal planktonic ecosysytems. In: Tsukamoto K, Kawamura T, Takeuchi T, Beard TD Jr, Kaiser MJ (eds) Fisheries for global welfare and environment. Proc 5th World Fisheries Congress 2008, Terrapub, Tokyo, p 181-196

Olsen Y, Andersen T, Gismervik I, Vadstein O (2007) Protozoan and metazoan zooplankton-mediated carbon flows in nutrient-enriched coastal planktonic communities. Mar Ecol Prog Ser 331:67-83

> Olsen Y, Andersen T, Gismervik I, Vadstein O (2011) Marine 
heterotrophic bacteria, protozoan and metazoan zooplankton may experience protein $\mathrm{N}$ or mineral P limitation in coastal waters. Mar Ecol Prog Ser 436:81-100

Opstvedt J, Aksnes A, Hope B, Pike IH (2003) Efficiency of feed utilization in Atlantic salmon (Salmo salar L.) fed diets with increasing substitution of fish meal with vegetable proteins. Aquaculture 221:365-379

Palenik B, Morel FMM (1990) Amino-acid utilization by marine-phytoplankton: a novel mechanism. Limnol Oceanogr 35:260-269

Peharda M, Zupan I, Bavcevic L, Frankic A, Klanjscek T (2007) Growth and condition index of mussel Mytilus galloprovincialis in experimental integrated aquaculture. Aquacult Res 38:1714-1720

Penczak T, Galicka W, Molinski M, Kusto E, Zalewski M (1982) The enrichment of a mesotrophic lake by carbon, phosphorus and nitrogen from the cage aquaculture of rainbow trout, Salmo gairdneri. J Appl Ecol 19:371-393

Pérez O (2002) Geographical Information Systems (GIS) as a simple tool to aid modelling of particulate waste distribution at marine fish cage sites. Estuar Coast Shelf Sci 54: 761-768

Petersen SA, Sutherland TF, Higgs D (2005) Physical and chemical characterization of salmonid feed pellets. Can Data Rep Fish Aquat Sci 1159, Fisheries and Oceans Canada, West Vancouver, BC

> Phillips MJ, Beveridge MCM, Ross LG (1985) The environmental impact of salmonid cage culture on inland fisheries: present status and future trends. J Fish Biol 27: 123-137

Piedecausa MA, Aguado-Giménez F, García-García B, Telfer TC (2010) Total ammonia nitrogen leaching from feed pellets used in salmon aquaculture. J Appl Ichthyology 26:16-20

Piedrahita RH (2003) Reducing the potential environmental impact of tank aquaculture effluents through intensification and recirculation. Aquaculture 226:35-44

Porrello S, Lenzi M, Tomassetti P, Persia E, Finoia MG, Mercatali I (2003) Reduction of aquaculture wastewater eutrophication by phytotreatment ponds system: II. Nitrogen and phosphorus content in macroalgae and sediment. Aquaculture 219:531-544

> Qian PY, Wu CY, Wu M, Xie YK (1996) Integrated cultivation of the red alga Kappaphycus alvarezii and the pearl oyster Pinctada martensi. Aquaculture 147:21-35

Redmond KJ, Magnesen T, Hansen PK, Strand O, Meier S (2010) Stable isotopes and fatty acids as tracers of the assimilation of salmon fish feed in blue mussels (Mytilus edulis). Aquaculture 298:202-210

Reid GK, Liutkus M, Robinson SMC, Chopin TR and others (2009) A review of the biophysical properties of salmonid faeces: implications for aquaculture waste dispersal models and integrated multi-trophic aquaculture. Aquacult Res 40:257-273

Sanz-Lázaro C, Marín A (2011) Diversity patterns of benthic macrofauna caused by marine fish farming. Diversity 3: 176-199

Schuenhoff A, Shpigel M, Lupatsch I, Ashkenazi A, Msuya FE, Neori A (2003) A semi-recirculating, integrated system for the culture of fish and seaweed. Aquaculture 221: $167-181$

Skogen MD, Eknes M, Asplin LC, Sandvik AD (2009) Modelling the environmental effects of fish farming in a Norwegian fjord. Aquaculture 298:70-75

Skriptsova AV, Miroshnikova NV (2011) Laboratory experiment to determine the potential of two macroalgae from the Russian Far-East as biofilters for integrated multi- trophic aquaculture (IMTA). Bioresour Technol 102: 3149-3154

Smaal AC, Vonck APMA (1997) Seasonal variation in C, N and $\mathrm{P}$ budgets and tissue composition of the mussel Mytilus edulis. Mar Ecol Prog Ser 153:167-179

Sterner RW, George NB (2000) Carbon, nitrogen, and phosphorus stoichiometry of cyprinid fishes. Ecology 81: $127-140$

Stirling HP, Okumus I (1995) Growth and production of mussels (Mytilus edulis L.) suspended at salmon cages and shellfish farms in two scottish sea lochs. Aquaculture 134:193-210

Stoecker DK, Gustafson DE Jr (2003) Cell-surface proteolytic activity of photosynthetic dinoflagellates. Aquat Microb Ecol 30:175-183

Sugiura SH, Marchant DD, Kelsey K, Wiggins T, Ferraris RP (2006) Effluent profile of commercially used low-phosphorus fish feeds. Environ Pollut 140:95-101

Talbot C, Preston T, East BW (1986) Body-composition of atlantic salmon (Salmo salar L.) studied by neutron-activation analysis. Comp Biochem Physiol A 85:445-450

Tett P (2008) Fish farm wastes in the ecosystem In: Holmer M, Black K, Duarte CM, Marbà N, Karakassis I (eds) Aquaculture in the ecosystem. Springer, Dordrecht

> Troell M, Norberg J (1998) Modelling output and retention of suspended solids in an integrated salmon-mussel culture. Ecol Modell 110:65-77

Troell M, Halling C, Nilsson A, Buschmann AH, Kautsky N, Kautsky L (1997) Integrated marine cultivation of Gracilaria chilensis (Gracilariales, Rhodophyta) and salmon cages for reduced environmental impact and increased economic output. Aquaculture 156:45-61

Troell M, Halling C, Neori A, Chopin T, Buschmann AH, Kautsky N, Yarish C (2003) Integrated mariculture: asking the right questions. Aquaculture 226:69-90

Troell M, Joyce A, Chopin T, Neori A, Buschmann AH, Fang JG (2009) Ecological engineering in aquaculturepotential for integrated multi-trophic aquaculture (IMTA) in marine offshore systems. Aquaculture 297:1-9

- Tsagaraki TM, Petihakis G, Tsiaras K, Triantafyllou G and others (2011) Beyond the cage: ecosystem modelling for impact evaluation in aquaculture. Ecol Modell 222: 2512-2523

Vandenberg GW, De La Noüe J (2001) Apparent digestibility comparison in rainbow trout (Oncorhynchus mykiss) assessed using three methods of faeces collection and three digestibility markers. Aquacult Nutr 7:237-245

Vassallo P, Doglioli AM, Rinaldi F, Beiso I (2006) Determination of physical behaviour of feed pellets in Mediterranean water. Aquacult Res 37:119-126

Vollenweider RA (1976) Advances in defining critical load levels for phosphorus in lake eutroophication. Mem Ist Ital Idrobiol 33:53-83

> Whitmarsh DJ, Cook EJ, Black KD (2006) Searching for sustainability in aquaculture: an investigation into the economic prospects for an integrated salmon-mussel production system. Mar Policy 30:293-298

- Wong KB, Piedrahita RH (2000) Settling velocity characterization of aquacultural solids. Aquacult Eng 21:233-246

> Yang HS, Zhou Y, Hu HY, Liu Y and others (2006) Bioremediation potential of the macroalga Gracilaria lemaneiformis (Rhodophyta) integrated into fed fish culture in coastal waters of north China. Aquaculture 252:264-276

Yokoyama H, Inoue M, Abo K (2004) Estimation of the assimilative capacity of fish-farm environments based on the current velocity measured by plaster balls. Aquaculture 240:233-247 